\title{
Annual and Monthly Variation in Species Composition and Catches of Fishes from the Tabusintac River Estuary in the Southern Gulf of St. Lawrence
}

\author{
A. M. Herrell and D. A. Methven \\ Department of Biology and Canadian Rivers Institute, University of New Brunswick, Saint John, New Brunswick E2L 4L5 \\ Canada \\ Corresponding author: dmethven@unbsj.ca
}

Herrell, A. M., and D. A. Methven. 2009. Annual and Monthly Variation in Species Composition and Catches of Fishes from the Tabusintac River Estuary in the Southern Gulf of St. Lawrence. Canadian Field-Naturalist 123(1): 48-67.

A total of 7130 fish from 13 taxa were collected during summer and autumn, 2002-2005 using box traps at two sites in the Tabusintac River Estuary, New Brunswick, Canada. The objective was to determine seasonal change in species composition and catches, and to access change in annual returns of Atlantic Salmon, an important recreational fishery during autumn on the Tabusintac, Miramichi and neighboring rivers. Taxa richness and composition varied annually and from trap to trap. Richness ranged from 8-10 taxa annually and catches were usually highest in the trap closest to the ocean despite its slightly smaller size. Taxa contributing greater than one percent of the total catch during the four years of sampling included six diadromous taxa: Blueback Herring and Alewife (41.65\%), Striped Bass (21.54\%), Atlantic Salmon (3.98\%), Tomcod (2.95\%), Brook Trout (1.05\%), American Eel (5.27\%); one freshwater species, White Sucker (11.96\%); one marine species, Winter Flounder and one resident estuarine species, Smooth Flounder which together account for $11.19 \%$ of the total catch. The remaining five species (American Smelt, Northern Pipefish, White Perch, Cunner, Sea Lamprey) contributed 0.39\% of the total catch. The fish fauna 14-15 km up the Tabusintac River was not species rich, due in large part to the limited sampling time each year and due to fishing with just one sampling gear, a stationary box trap. Additional species would have been collected if smaller mesh sampling gear were used. Comparisons were made with other studies and the phenology of the dominant species on the Tabusintac and Miramichi River Estuaries during the ice free season is established. Most catches appear to be related to pre- or post-spawning movements of anadromous fishes.

Key Words: Atlantic Salmon, Salmo salar, anadromous fishes, migration, Tabusintac River Estuary, New Brunswick.

Canada has a relatively depauperate freshwater fish fauna, despite having a surface area of almost 10 million $\mathrm{km}^{2}$ and five extensive drainage basins that include several northern and Great Lakes $\left(>25,000 \mathrm{~km}^{2}\right)$ and many long rivers. The freshwater fish fauna consist of approximately 24 families containing less than 200 species (Scott and Crossman 1998). Five families Salmonidae, Catostomidae, Cyprinidae, Percidae, and Cottidae account for $70 \%$ of the fauna (Scott and Crossman 1998). Species richness is highest ( $>100$ species) in central Canada and lowest on Prince Edward Island and insular Newfoundland (20-25 species; Scott and Crossman 1998; Taylor 2004; Curry 2007). This low diversity relates to Canada's northern position and to extensive ice coverage during the Pleistocene.

The low richness of eastern Canada's freshwater fish fauna and the low richness of north temperate estuaries in general (Haedrich 1983; Sosa-Lopez and Mouillot 2007) suggest that catches of riverine and estuarine fishes in eastern Canada should be dominated by relatively few species. Fish assemblages in estuaries of Atlantic Canada are poorly studied despite the well known importance of estuaries as nursery and feeding grounds, and as places of exceptionally high productivity (Haedrich 1983). Numerous studies have been conducted on individual species but fish communities as a whole are described in only a handful of studies in Atlantic Canada. Of note are studies by McKenzie (1959), Chaput (1995), and Hanson and Courtenay (1995) who report on species composition and relative abundance of fishes in the Miramichi River and Estuary (c. $300 \mathrm{~km}^{2}$ ) in the southern Gulf of St. Lawrence. A total of 78 species were collected in the Miramichi River, its estuary and nearby marine waters (McKenzie 1959; Hanson and Courtenay 1995). This contrasts with 23 species collected in a more northerly, and much smaller estuary $\left(<10 \mathrm{~km}^{2}\right)$ at Bellevue Newfoundland that was sampled throughout the year at a single site (Methven et al. 2001).

Variability in species richness, composition and abundance of fishes in estuaries is related to several small and large scale spatial factors that include latitude, size of the estuary, and the location and number of habitats sampled (Haedrich 1983; Sosa-Lopez and Mouillot 2007). Temporal variability also has a significant bearing on species richness, composition, and abundance of fishes taken in estuaries and other coastal habitats. Temporal variation is assumed to be concentrated at periodic scales, e.g. tidal, diel, lunar, seasonal and annual (Laevastu and Hayes 1981), with numerous studies reporting high contrasts in catches and species richness of estuarine and coastal marine fishes at these 
scales (Dahlberg and Odum 1970; Gibson et al. 1996; Lazzari et al. 1999; Methven et al. 2001; deBruyn and Meeuwig 2001).

In this study we describe annual variation in species composition, catches and size structure of the dominant fishes taken in two stationary traps located 14$15 \mathrm{~km}$ up the Tabusintac River in the southern Gulf of St. Lawrence during summer and autumn, 20022005. We integrate our findings with previous studies and establish the phenology of the dominant species during the ice free season. The Tabusintac River Estuary is located less than $30 \mathrm{~km}$ from the much larger Miramichi Estuary. Together, these two estuaries contribute significantly to local commercial and recreational fisheries (McKenzie 1959; Chaput 1995; Comeau 2001a), an observation that is made repeatedly for estuarine based fisheries throughout the world (McHugh 1976; Pollard 1981; Haedrich 1983). Species in the commercial and recreational fisheries in the Tabusintac and Miramichi Rivers include Gaspereau (Alosa spp), American Eel (Anguilla rostrata), Atlantic Salmon (Salmo salar), American Smelt (Osmerus mordax), Tomcod (Microgadus tomcod) and Brook Trout (Salvelinus fontinalis) (McKenzie 1959; Chaput 1995; Comeau 2001a, 2001b).

\section{Methods}

All sampling was confined to the Tabusintac River Estuary in New Brunswick, Canada. The Tabusintac River drains into Tabusintac Bay in the southern Gulf of St. Lawrence. The river has more than 34 tributaries and a drainage area of $717 \mathrm{~km}^{2}$ (Comeau 2001a). The Tabusintac River, located just north of the Miramichi River, freezes over each year usually from December to April (Chaput 1995).

\section{Study sites}

Two study sites (designated MT $\left[47^{\circ} 20.283^{\prime} \mathrm{N}\right.$, $65^{\circ} 06.828^{\prime} \mathrm{W}$ ] and RT [ $\left.47^{\circ} 20.098^{\prime} \mathrm{N}, 65^{\circ} 07.948^{\prime} \mathrm{W}\right]$ ) were located on the main branch of the Tabusintac River. The MT site was located on the south side of the river in an area of low water flow with a substratum of small rocks nearshore, and mud in the central channel. The Tabusintac River measures approximately 160 meters wide and 4-5 meters deep at low tide at the MT site. The RT site was located $1.5 \mathrm{~km}$ further upstream on the north side of the river. The sites share similar habitat characteristics and a tidal amplitude of approximately 0.6-0.8 meters. Refer to Comeau (2001b) for additional information on the location of the two box traps (described below) in the Tabusintac River.

\section{Trap description}

Fish were collected in $\mathrm{Y}$ shaped box traps from 2002-2004 and T shaped box traps in 2005. One trap was located at each sampling site. Traps were secured by wooden pickets and brace work and were rectangular in shape with a short side to long side ratio of at least 1:4 (Dunfield 1974). The Y trap at the MT site measured $14.96 \times 3.67$ meters $(50 \mathrm{~mm}$ stretch mesh) and had two leaders of different lengths (30.48 and $45.72 \mathrm{~m}$ ), both with $71 \mathrm{~mm}$ stretch mesh. The $\mathrm{Y}$ trap at the RT site was slightly larger $15.26 \times 3.67 \mathrm{~m}(50 \mathrm{~mm}$ stretch mesh) and also had two leaders (30.48 and $45.72 \mathrm{~m}$ ) both with $139 \mathrm{~mm}$ stretched mesh. Both T traps (2005) measured $18.90 \times 3.35$ meters $(50 \mathrm{~mm}$ stretched mesh) and had a single 45.72 meter long leader with $47 \mathrm{~mm}$ stretched mesh. Y and T traps were located at the same sites each year (to within approximately five $\mathrm{m}$ ) in approximately two meters of water at low tide. Traps were located approximately 46 meters from the shore each year. Initial formation of ice at both sites resulted in the traps being removed from the water by early November.

\section{Fish collections}

Fish were collected in both traps from late July to early November. However, dates of sampling varied among years (Table 1). Traps were sampled between 08:00-10:00 hrs each day except on days when winds were too high to safely travel by boat or on days when traps were being repaired and cleaned. The number of days that the traps were not sampled each year is given in Table 1 as the difference between total days that traps were in the water and sample days, i.e., the number of days the traps were checked (Table 1). For example, traps were not checked for two days in 2002 (Table 1). Water temperature was taken in 2002 using a VEMCO 8-bit Minilog-TR that recorded once daily at approximately $30 \mathrm{~cm}$ depth. Water temperature was taken daily using a hand held alcohol thermometer at approximately $30 \mathrm{~cm}$ below the surface in 2003-2005.

Fish were identified to species with the exception of Alosa pseudoharengus - A. aestivalis and Pseudopleuronectes americanus - Pleuronectes putnami. Both species of Alosa were tentatively, but not routinely identified beginning in 2001. We refer to the combined catches of these two species as Alosa spp. We investigated if we were catching both Pseudopleuronectes americanus (Winter Flounder) and Pleuronectes putnami (Smooth Flounder) by examining several collections taken in September and October 2007 ( $n=30$ specimens). Both species were present in the collections we examined in 2007 (19 Pseudopleuronectes americanus; 11 Pleuronectes putnami) and we conclude that both species were very likely present in 2002-2005. The 30 specimens of Pseudopleuronectes americanus (12.2$22.4 \mathrm{~cm}$ ) and Pleuronectes putnami $(13.6-27.7 \mathrm{~cm})$ were deposited in the New Brunswick Museum in Saint John (NBM Catalogue Numbers 2256-2277). These species were distinguished using anal finray counts (Collette and Klein-MacPhee 2002), a character that did not overlap for the 30 specimens we examined (Winter Flounder: range 42-49, mean 46.4; Smooth Flounder: range 36-41, mean 37.7). Mature male Atlantic Salmon were separated from females by the presence of a kype, a distinctive hooked jaw that males develop during spawning (Scott and Scott 1988). All Morone saxatilis, 
TABLE 1. Dates, duration (total days) and number of sampling days for each trap (MT, RT) on the Tabusintac River 2002 to 2005.

\begin{tabular}{lllcc}
\hline \hline Year & Trap & Dates & $\begin{array}{c}\text { Total } \\
\text { days }\end{array}$ & $\begin{array}{c}\text { Sample } \\
\text { days }\end{array}$ \\
\hline 2002 & MT & 19 September - 8 November & 51 & 49 \\
& RT & 19 September - 8 November & 51 & 49 \\
2003 & MT & 22 July - 26 October & 97 & 90 \\
& RT & 22 July - 26 October & 97 & 90 \\
2004 & MT & 21 July - 26 September & 68 & 62 \\
& RT & 21 July - 26 September & 68 & 62 \\
2005 & MT & 4 August - 10 October & 68 & 64 \\
& RT & 12 August - 11 October & 61 & 57 \\
\hline \hline
\end{tabular}

Salmo salar and Anguilla rostrata were measured to the nearest $0.5 \mathrm{~cm}$ Fork Length (Total Length [TL] for Anguilla rostrata). All fish taken during this study were returned to the water alive except 41 Salmo salar and one Alosa spp. that were harvested as part of the Burnt Church First Nation food fishery.

Data are summarized in Table 2 by presenting total number of fish caught for each species in each trap (MT, RT) for each year (2002 to 2005). Number of sampling days was consistent within each year for the MT and RT traps except in 2005 (Table 1). Taxa richness was determined based on the number of individual species (or taxa) taken in each trap (Table 2). For example, richness was 10 taxa for the MT trap in 2002, two of which had the same rank abundance (Table 2).

\section{Results}

Overall, a total of 7130 fish from 13 taxa were caught during the four years of sampling (Table 2). Taxa richness ranged from 8-10 depending on the trap and year of sampling (Table 2). The maximum difference in taxa richness between the MT and RT traps in any given year was two (Table 2). Total catch and taxa richness were consistently higher at the MT site located closest to the ocean (Table 2) despite this trap being slightly smaller in size. Fishes captured in both traps during the four years of sampling in decreasing order of catch included (Table 2): Alosa spp. (41.65\%), M. saxatilis (21.54\%), C. commersoni (11.96\%), Pseudopleuronectes americanus - Pleuronectes putnami (11.19\%), A. rostrata (5.27\%), S. salar (3.98\%), M. tomcod $(2.95 \%)$ and S. fontinalis $(1.05 \%)$. The remaining species (Osmerus mordax $n=2$; Syngnathus fuscus $n=1$; Petromyzon marinus $n=2$; Morone americana $n=22$; Tautogolabrus adspersus $n=1$ ) contributed only $0.39 \%$ of the total catch. In addition, sticklebacks (Gasterosteidae) were also observed but seldom retained in the mesh of the traps. Several non-fish species were also collected: one Beaver (Castor canadensis, 2003 RT) was dead when found, one Cormorant (Phalacrocorax spp., 2004 MT) that died, 16 Red Breasted Mergansers (Mergus serrator, $2004 \mathrm{RT} n=11 ; 2005$
MT $n=5$, no mortality) plus numerous jellyfish of the genera Aurelia and Cyanea.

Some of the annual variation in taxa richness and total catch was due to the different dates of trap deployment and retrieval each year (Table 1). When data were standardized (i.e., examined for the common days sampled in 2003-2005 (46 days: 12 August to 26 September), the five most abundant taxa taken in the MT trap were (Table 2): M. saxatilis (31.37\%), Alosa spp. (26.38\%), Pseudopleuronectes americanus - Pleuronectes putnami (19.29\%), C. commersoni (17.23\%) and A. rostrata $(2.51 \%)$. This ranking is generally similar to the RT trap over the same time period (Table 2): M. saxatilis (50.70\%), Alosa spp. (16.32\%), C. commersoni (12.81\%), Pseudopleuronectes americanus Pleuronectes putnami $(8.07 \%)$ and S. salar $(4.56 \%)$. 2002 was not included in this comparison (of common days) because there was only eight days of sampling in 2002 that overlapped with sampling in 20032005. Taxa richness and total catch were still highest in the MT trap when data were examined for the 46 common days of sampling (Table 2) indicating richness and total catch increase when sampling towards the ocean.

Little variation in water temperature was observed between the two traps on any given day of sampling despite the traps being $1.5 \mathrm{~km}$ apart. Hence annual correlations ( $\mathrm{r}$ ) of daily water temperatures were high (2002: 0.987; 2003: 0.964; 2004: 0.959; 2005: 0.999).

Mean water temperatures were essentially identical when calculated for the 46 common days of sampling each year (2003: MT $17.7^{\circ} \mathrm{C}$, RT $17.4^{\circ} \mathrm{C} ; 2004$ : MT $19.5^{\circ} \mathrm{C}$, RT $19.3^{\circ} \mathrm{C}$; 2005 : MT $19.6^{\circ} \mathrm{C}$, RT $19.6^{\circ} \mathrm{C}$ ). Water temperature was generally highest in late July and early August (c. $23^{\circ} \mathrm{C}$ ) and declined rapidly from mid September $\left(\right.$ c. $\left.18^{\circ} \mathrm{C}\right)$ to late October $\left(\right.$ c. $\left.5^{\circ} \mathrm{C}\right)$ (Figure 1). Throughout the course of study (21 July to 8 November, 2002-2005) water temperature ranged from a low of $0.2^{\circ} \mathrm{C}$ (RT, 20 October 2002) to a high of $27^{\circ} \mathrm{C}$ (MT, 5 August 2004).

Field notes were kept on species marked by Sea Lamprey, Petromyzon marinus, as evidenced by a char- 


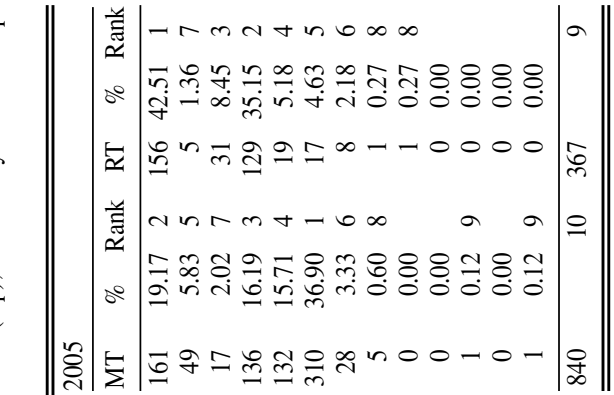

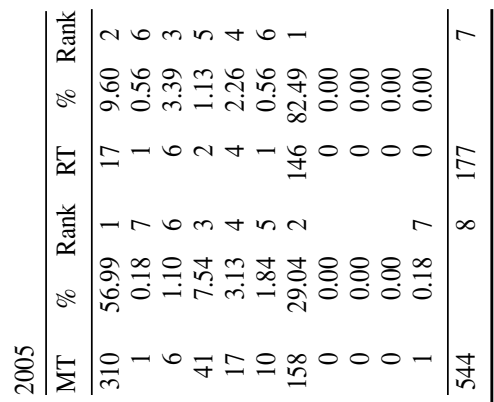

§ิ

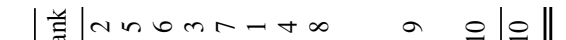

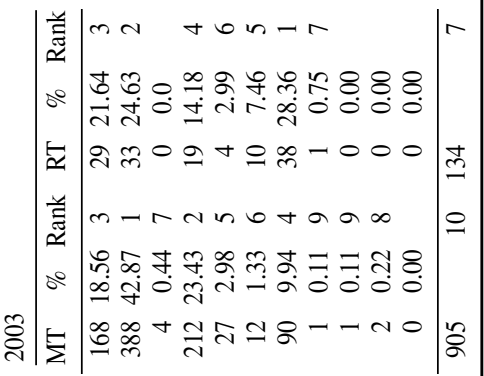




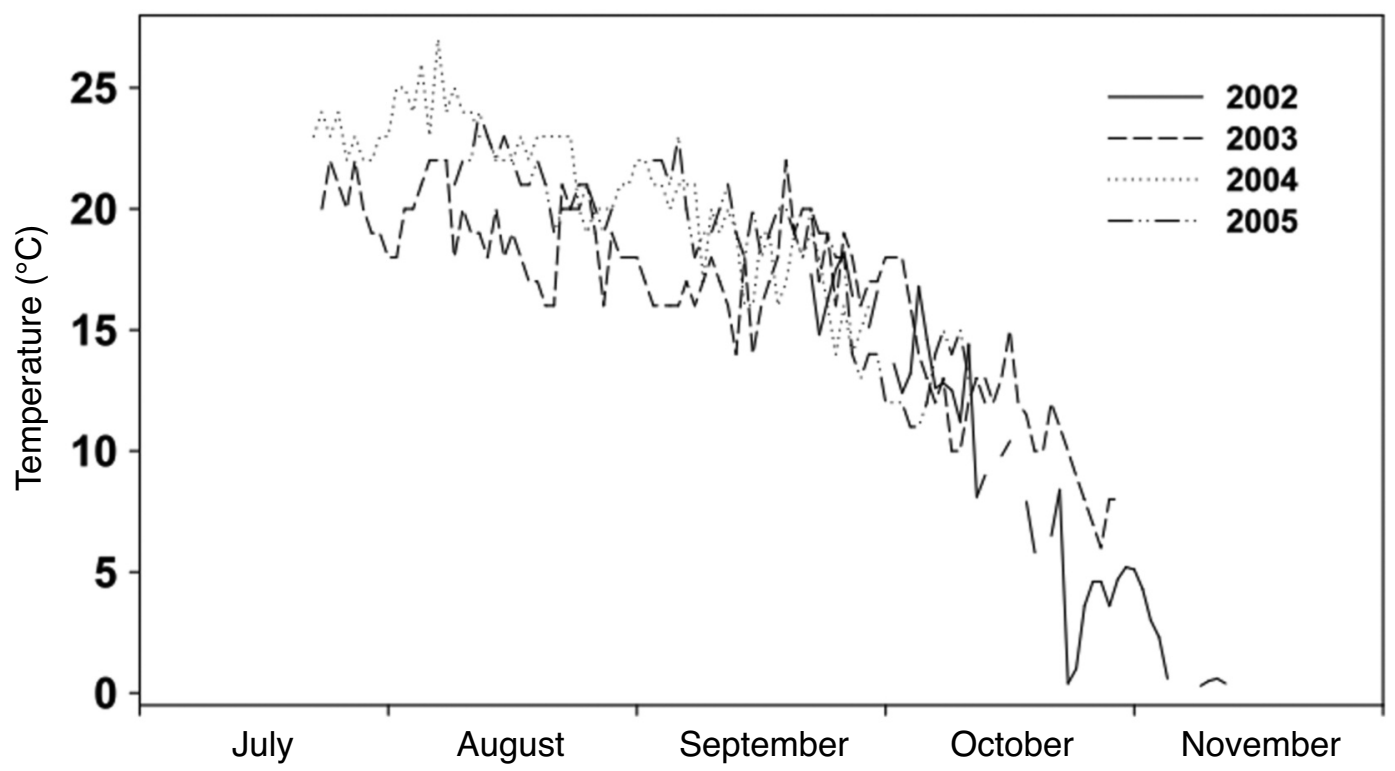

FIGURE 1. Variability in daily water temperatures $\left({ }^{\circ} \mathrm{C}\right)$ taken $30 \mathrm{~cm}$ below the surface at the MT site in the Tabusintac River 2002-2005.

acteristic circular wound due to rasping of scales and flesh with the lingual teeth of their sucker like mouths. Two species, $M$. tomcod ( $\mathrm{n}=2$ fish in 2003, one with one mark on the caudal peduncle, the other with two marks on the lower body) and $A$. rostrata $(n=2,2004$, 2005; one with a mark on its head and the other with a mark on its back) were observed with Sea Lamprey wounds. Only one Sea Lamprey was caught in the traps during the four years of study (13 August 2005 MT, $65 \mathrm{~cm})$. This Sea Lamprey may have been knocked off its host when the trap was hauled.

The two Alosa species (Alosa pseudoharengus, A. aestivalis; Alewife, Blueback) were not consistently distinguished from each other in our study. Together these two species accounted for $41.65 \%$ of the total catch (2002-2005, Table 2). Alosa spp. were caught throughout the sampling period with highest catches in mid July and early August at water temperatures of $\sim 18-24^{\circ} \mathrm{C}$ (Figure 2 ). Alosa spp. were occasionally caught at temperatures as low as $5^{\circ} \mathrm{C}$ in 2002 . Highest temperature of capture was $27^{\circ} \mathrm{C}$ but few fish were caught at temperatures greater than $25^{\circ} \mathrm{C}$. Alosa spp. were not measured, but most fish were approximately $25 \mathrm{~cm}$ FL.

Morone saxatilis was the second most abundant species taken during the four years of overall sampling (21.54\%, Table 2). It was the dominant species taken at both the MT (31.37\%) and RT (50.70\%) sites when data were examined from 12 August to 26 September (Table 2). Catches of Morone saxatilis were highest at the RT site for each of the standardized col- lections (Table 2). Morone saxatilis was taken each year throughout the sampling period with highest catches from September to November as water temperature declined (Figure 3). Morone saxatilis was predominantly caught at water temperatures between $10-25^{\circ} \mathrm{C}(2003-2005)$ but was taken at temperatures as low as $0.2^{\circ} \mathrm{C}$ in late October 2002 (Figure 3). Lengths of Morone saxatilis ranged overall from $5.0-81.9 \mathrm{~cm}$ FL there being three size modes present at approximately 10-15, 25-35 and 45-65 cm FL (Figure 4).

Catches of C. commersoni ranked it as the third dominant species overall (11.96\%, Table 2) but when data were standardized and compared for the common days of sampling (2003-2005) it ranked fourth (16.39\%, Table 2). Ranking ranged from first in 2003 (MT) to seventh in 2005 (MT). At times, this species could be very abundant with catches exceeding 100 fish (per trap per day) on two occasions (2003 MT, Figure 5). Catostomus commersoni was most abundant from late August to early October at water temperatures of 10$20^{\circ} \mathrm{C}$. Timing of peak catches varied considerably from year to year (Figure 5).

The two flatfishes, Pseudopleuronectes americanus and Pleuronectes putnami ranked as the fourth dominant taxa overall, (11.19\%, Table 2) and ranked third (17.16\%, Table 2) when examined from 12 August to 26 September 2003-2005. Catches were consistently much higher at the MT site (Table 2). Catches were relatively constant throughout the sampling period but could be punctuated and occasionally exceeded 20 fish per trap-day in late July and late August (Fig- 

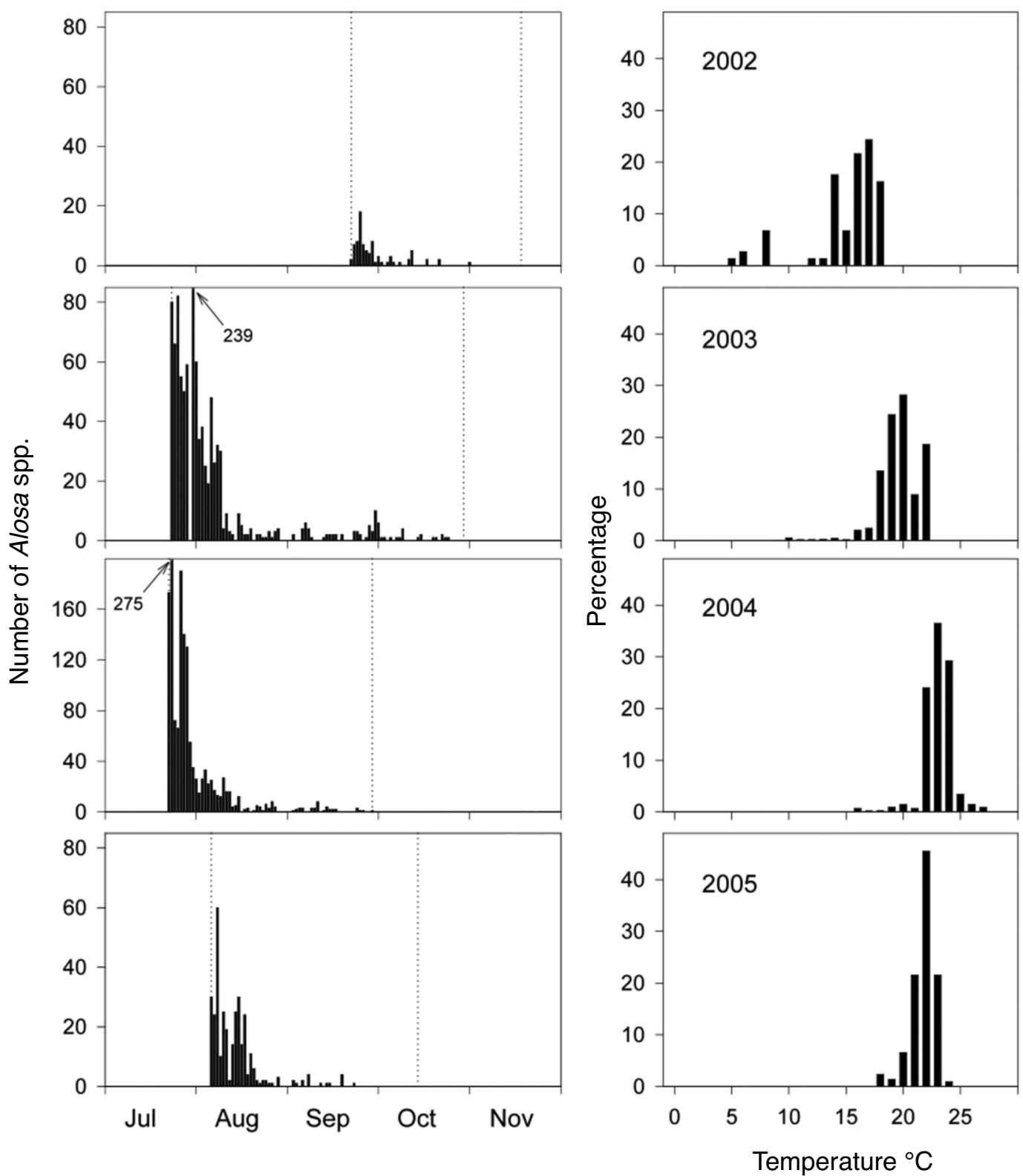

FIGURE 2. Daily catches of Blueback Herring and Alewife (Alosa spp.) from the combined catches of both traps (MT + RT) in the Tabusintac River 2002-2005. Dotted vertical lines represent the beginning and end of sampling. Right side panels show catches (as percent) in relation to temperature.

ure 6). Catches were highest at temperatures between $8-20^{\circ} \mathrm{C}$ but these species were caught at a broad range of temperatures from $0.4-27^{\circ} \mathrm{C}$ (Figure 6).

Anguilla rostrata had an overall rank of five (5.27\%, Table 2) and also ranked fifth $(2.80 \%$, Table 2$)$ when common days of sampling were compared among years (2003-2005). Catches were highest in October at water temperatures of approximately $10-20^{\circ} \mathrm{C}$ (Figure 7). It is difficult to identify size modes given that most A. rostrata were from $55-80 \mathrm{~cm}$ TL with very few caught at sizes less than $40 \mathrm{~cm}$ (Figure 8). There is no evidence of growth as indicated by increase in 

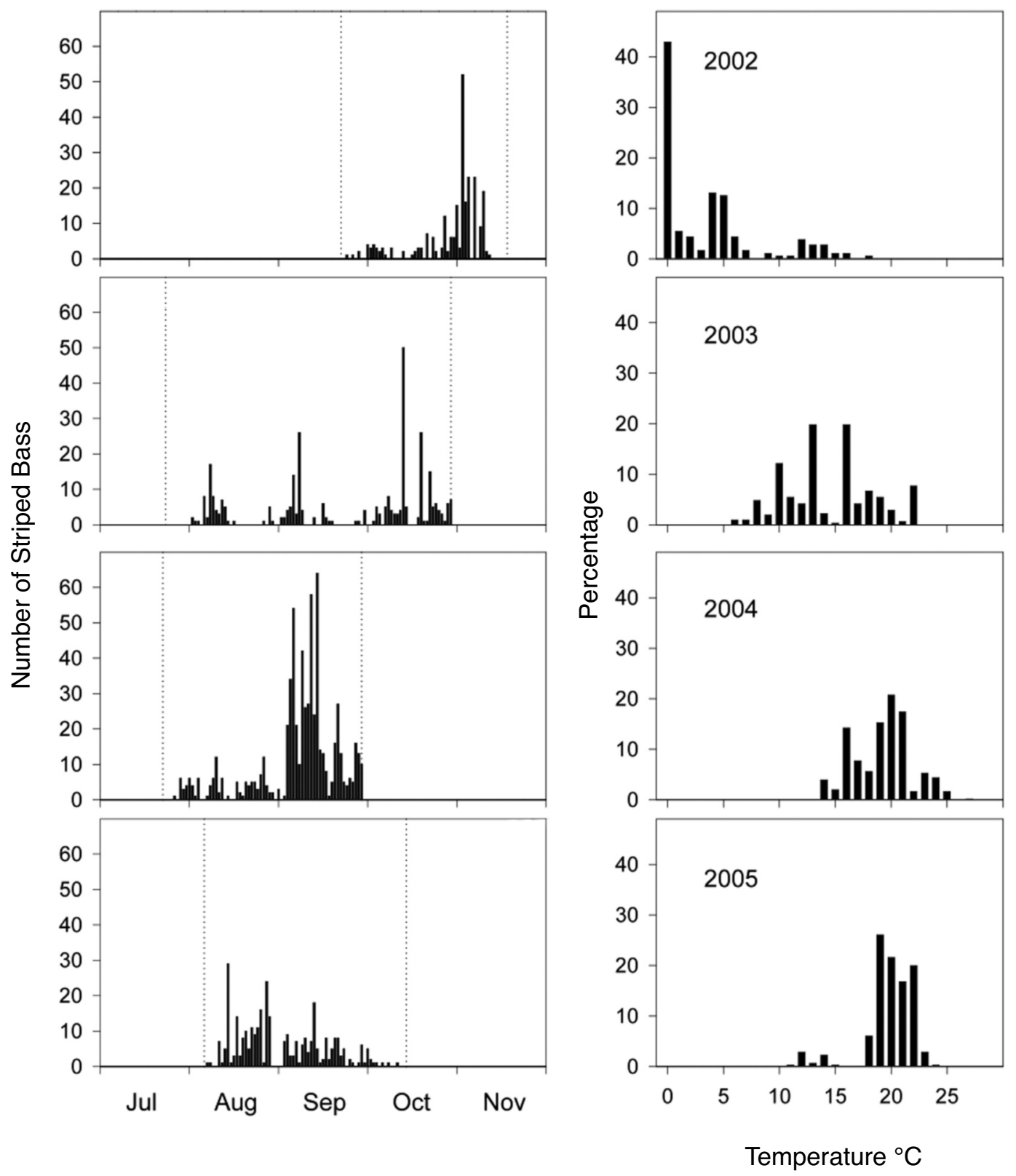

FIgURE 3. Daily catches of Striped Bass (Morone saxatilis) from the combined catches of both traps (MT + RT) in the Tabusintac River 2002-2005. Dotted vertical lines represent the beginning and end of sampling. Right side panels show catches (as percent) in relation to temperature.

modal sizes in any of the years examined (Figure 8). Activity is reported to be highest at night when feeding is thought to occur (Hanson and Courtenay 1995) and when movement is apparently stimulated by rainfall (Collette and Klein-MacPhee 2002). Our highest catch (2 October 2005, n=23, MT; Figure 7) occurred during a rain-free period from 28 September to 7 October 2005 .

Salmo salar ranked sixth overall $(3.98 \%$, Table 2$)$ and maintained the same rank when years were compared for common days of sampling from 12 August to 26 September $(2.24 \%, 2003-2005$, Table 2). Catch- 

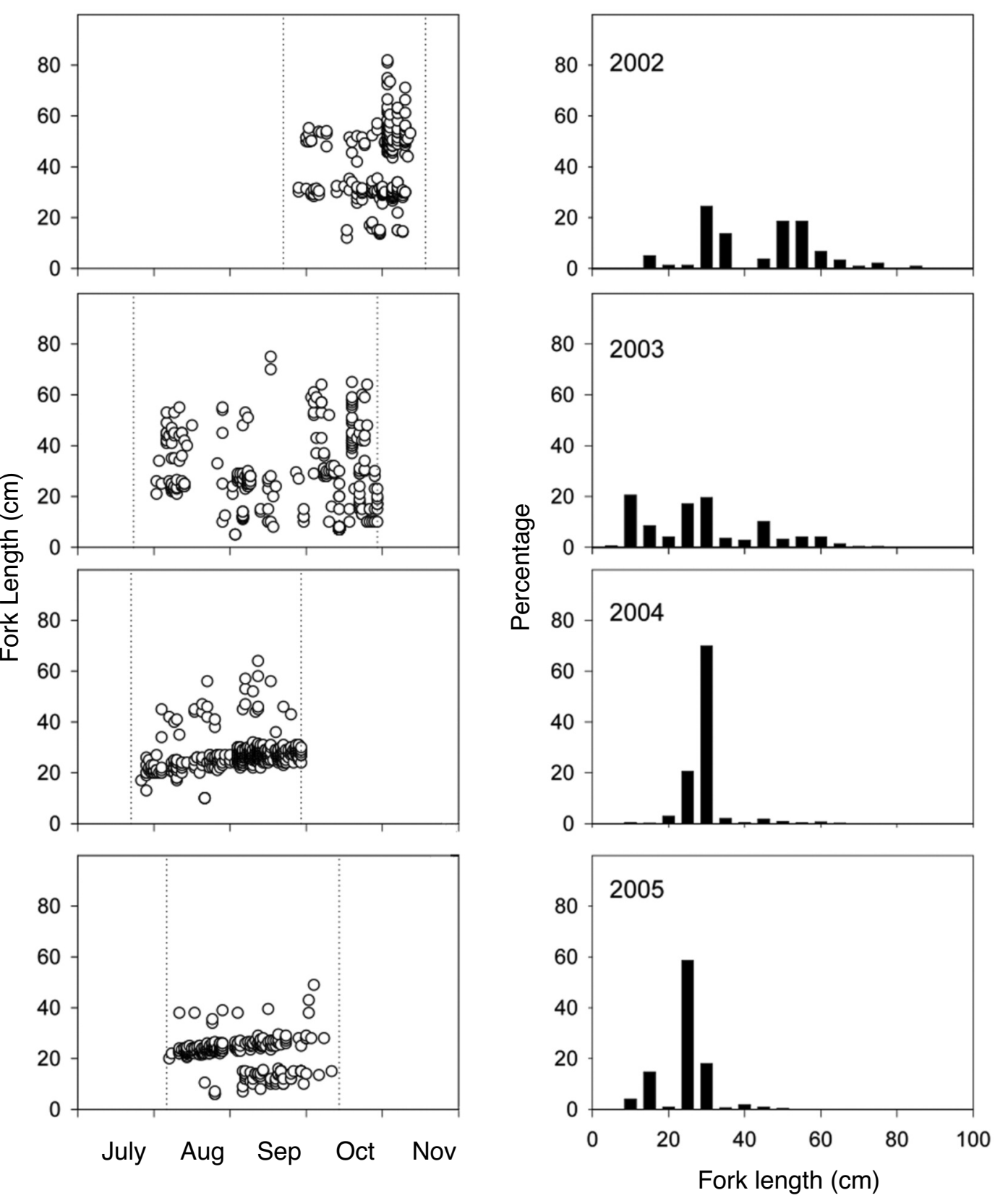

FIGURE 4. Daily lengths of individual Striped Bass (Morone saxatilis) and length frequencies (as percent) calculated from both traps combined (MT + RT) in the Tabusintac River 2002-2005. Dotted vertical lines represent the beginning and end of sampling.

es were highest in late September and throughout October at water temperatures of $5-17^{\circ} \mathrm{C}$ (Figure 9). Salmo salar were caught at temperatures as low as $0.4^{\circ} \mathrm{C}$ and as high as $25^{\circ} \mathrm{C}$ (Figure 9). Catches never exceeded 8 fish in a trap on any given day (Figure 9). When all data are examined, catches declined from
2002 to 2005 (Table 2). However, catches showed no consistent increasing or decreasing trend when the data were standardized (12 August to 26 September) and compared among years (2003: $n=4 ; 2004: n=23$; 2005: $n=12$ ). Catches were highest at the MT site in all years except 2005 (Table 2). Three size modes were 

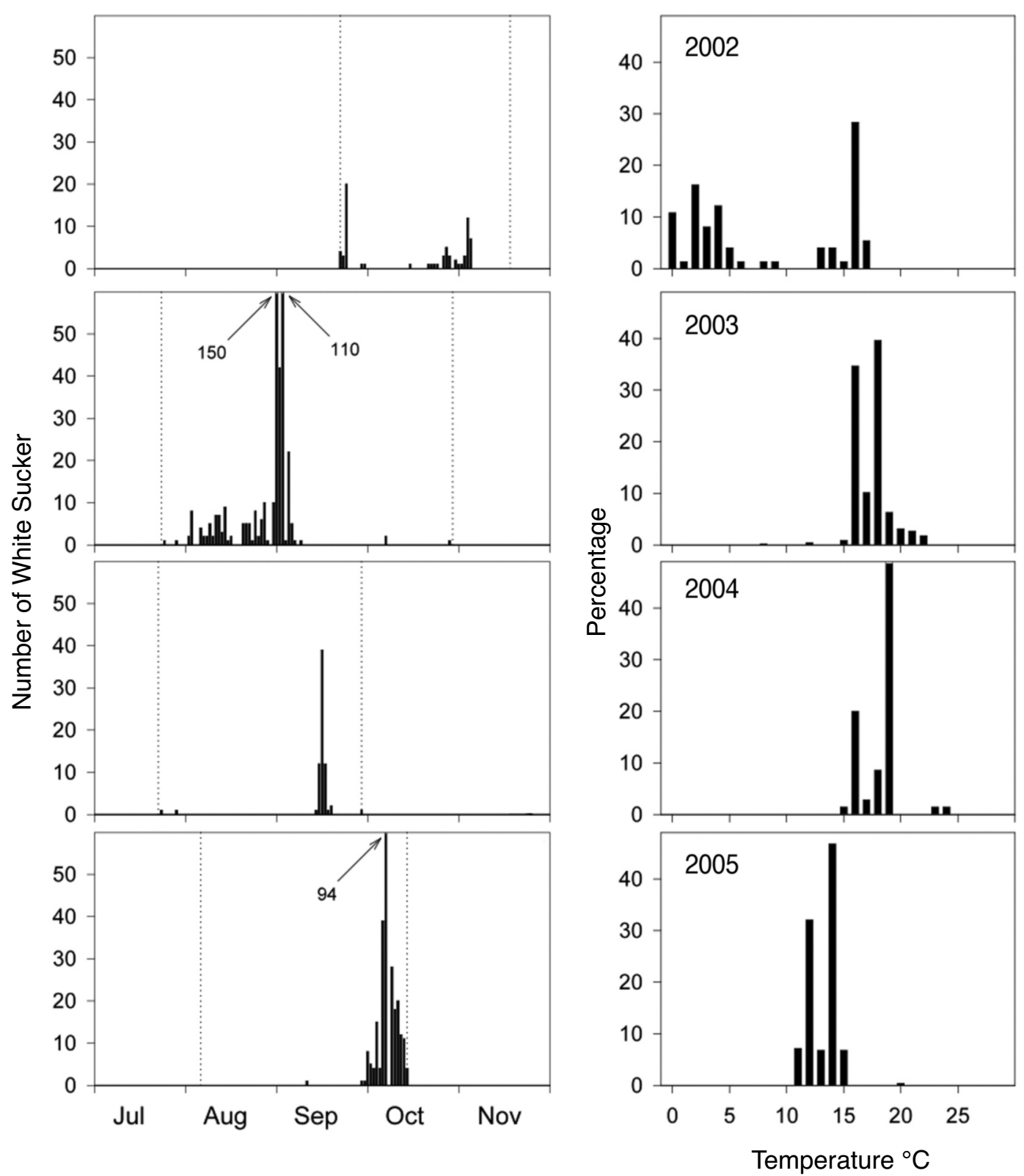

FIGURE 5. Daily catches of White Sucker (Catostomus commersoni) from the combined catches of both traps (MT + RT) in the Tabusintac River 2002-2005. Dotted vertical lines represent the beginning and end of sampling. Right side panels show catches (as percent) in relation to temperature.

observed at approximately 55-65, 75-85 and 95-105 cm FL (Figure 10). The smallest mode 55-65 cm FL, consisted overwhelming of males $(96.8 \%)$ with females dominating the two larger modes $(68.95 \%)$ (Figure 10).

Overall M. tomcod was ranked seventh, a rank that it retained when the data were standardized (12 August to 26 September, 2003-2005) and compared among years (Table 2). Catches were highest at the MT site in all years except in 2004 (Table 2). Catches were highest in September and October at temperatures of 5$19^{\circ} \mathrm{C}$ although it was most abundant in 2002 (the year with the latest date of sampling) at temperatures less than $5^{\circ} \mathrm{C}$ (Figure 11). 


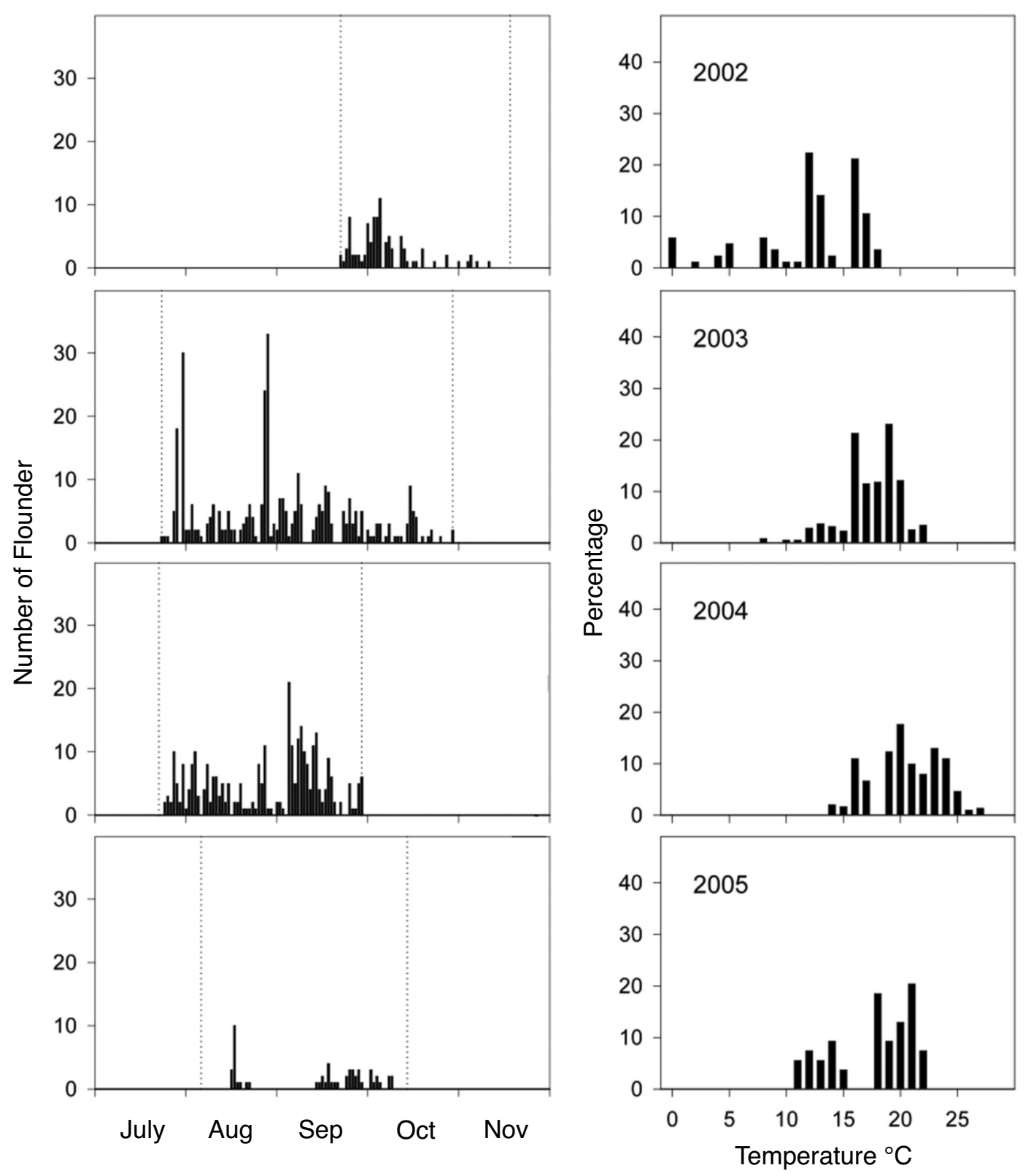

FIGURE 6. Daily catches of Winter Flounder (Pseudopleuronectes americanus) and Smooth Flounder (Pleuronectes putnami) from the combined catches of both traps (MT + RT) in the Tabusintac River 2002-2005. Dotted vertical lines represent the beginning and end of sampling. Right side panels show catches (as percent) in relation to temperature.

\section{Discussion}

The fish fauna of the Tabusintac River Estuary fit nicely within McHugh's (1967) six ecological categories of estuarine fishes. Of the dominant taxa sampled, C. commersoni was the only freshwater species taken. Pseudopleuronectes americanus was the only marine species and Pleuronectes putnami was the only estuarine species caught. Pleuronectes putnami moves seasonally within the Miramichi River and estuary, a large estuary approximately $30 \mathrm{~km}$ south of the Tabusintac River, where it apparently lives its entire life (Hanson and Courtenay 1997). Pleuronectes putnami may occur in slightly deeper coastal water in the Gulf of Maine (Collette and Klein-MacPhee 2002). The six 

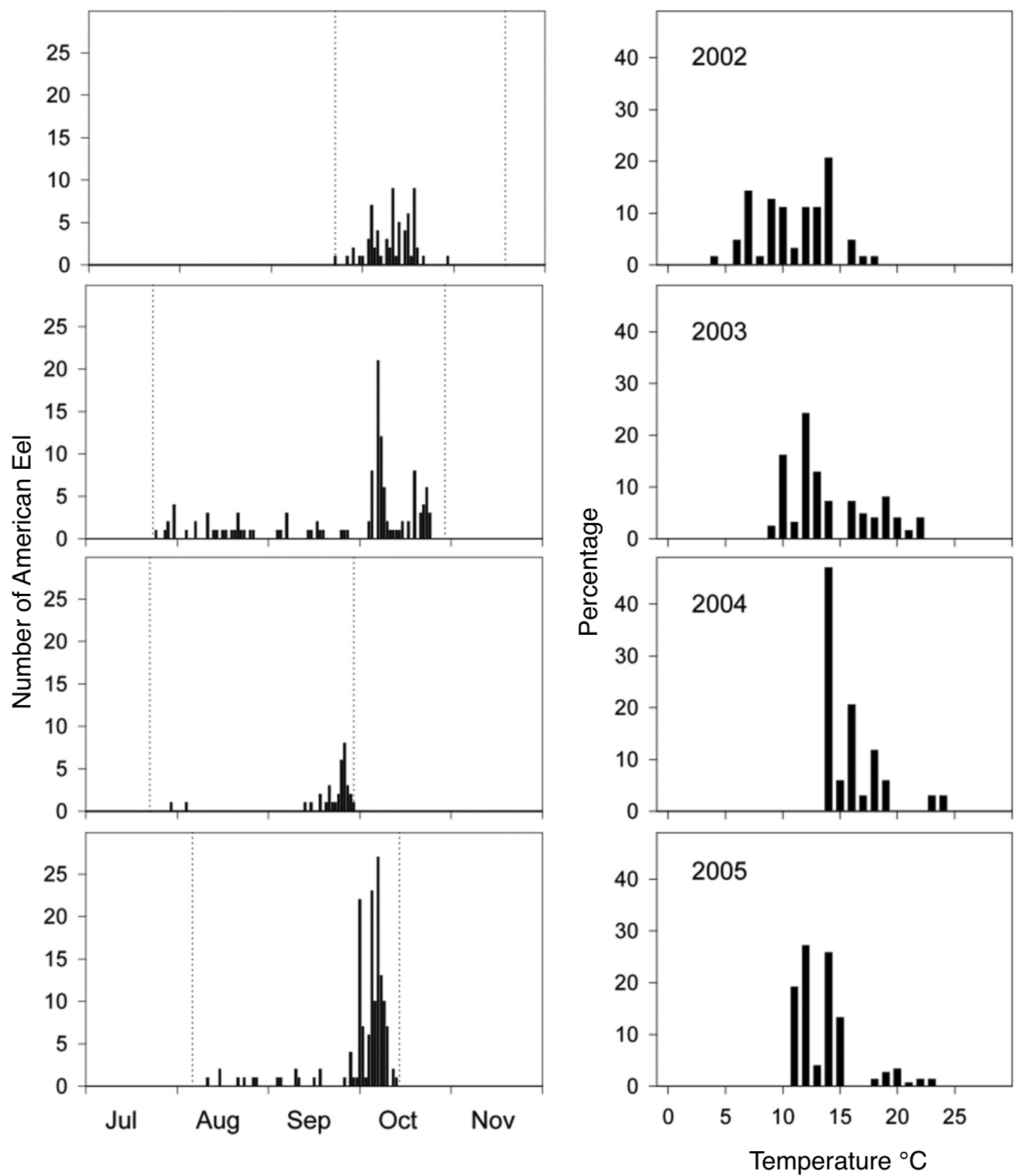

FIGURE 7. Daily catches of American Eel (Anguilla rostrata) from the combined catches of both traps (MT + RT) in the Tabusintac River 2002-2005. Dotted vertical lines represent the beginning and end of sampling. Right side panels show catches (as percent) in relation to temperature.

remaining dominant taxa were all diadromous (refer to McDowall 1987) and consisted of one catadromous eel, $A$. rostrata and five anadromous taxa including Alosa spp. (A. pseudoharengus, A. aestivalis), M. saxatilis, $S$. salar, $S$. fontinalis and $M$. tomcod.

The Tabusintac River Estuary fish assemblage contains several characteristics that identify it as a typical north temperate estuarine assemblage. The assemblage contains few species. The dominant species are primarily derived from marine forms, most of which are anadromous and seasonally abundant in rivers usually for the purposes of spawning and it seems, to a lesser extent for feeding. In addition, many of the species taken (e.g., Salmonidae, Clupeidae, American Eel, 

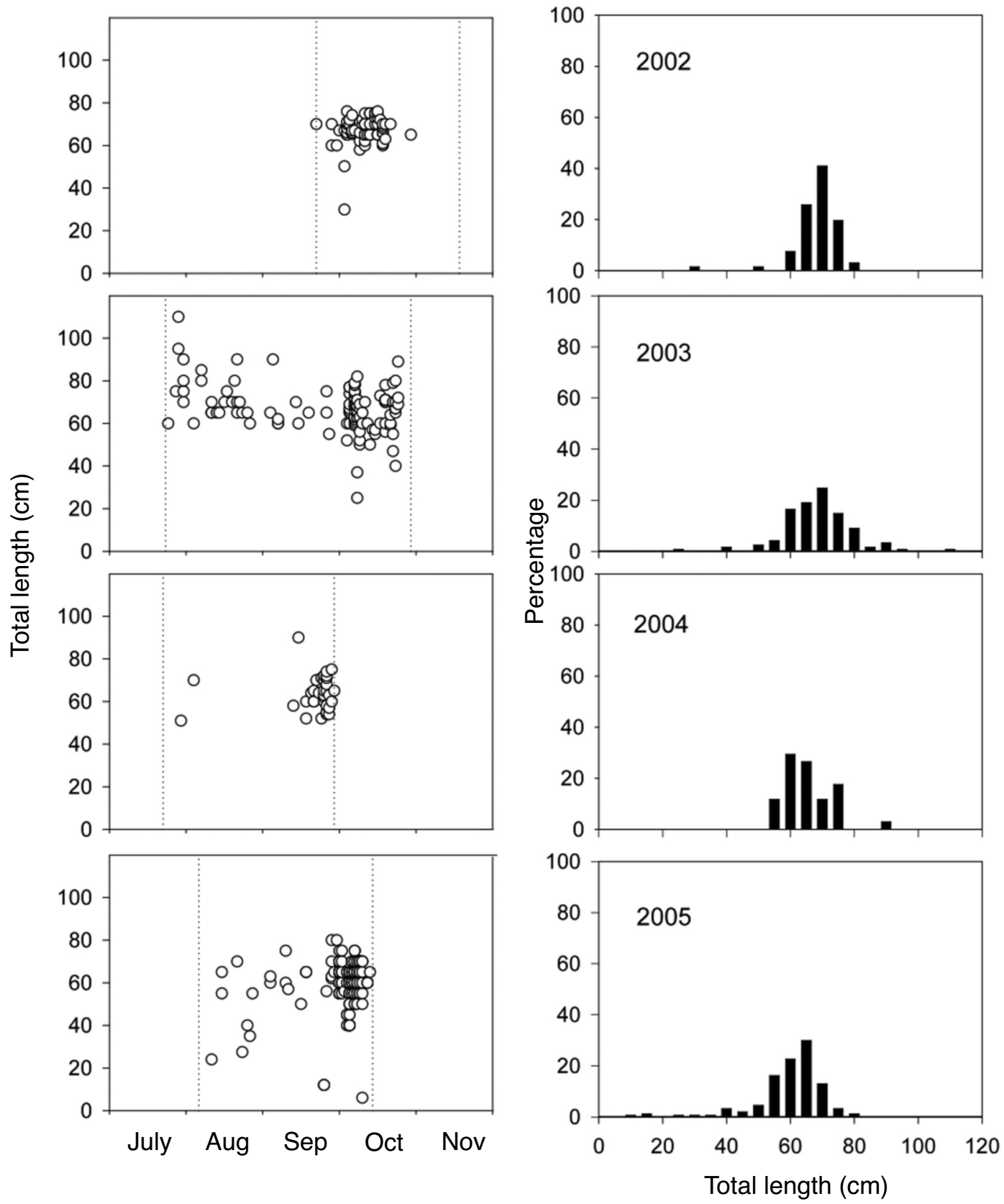

FIGURE 8. Daily lengths of individual American Eel (Anguilla rostrata) and length frequencies (as percent) calculated from both traps combined (MT + RT) in the Tabusintac River 2002-2005. Dotted vertical lines represent the beginning and end of sampling.

White Sucker, American Smelt, Sea Lamprey) contain primitive character sets as mentioned previously by McDowall (1987). This contrasts with tropical estuaries where anadromous species are rare and where species that spend their entire life in estuaries are more prominent (Haedrich 1983; McDowall 1987; Potter et al. 1990). In addition, some of the most important fish families listed by Haedrich (1983) that are char- 

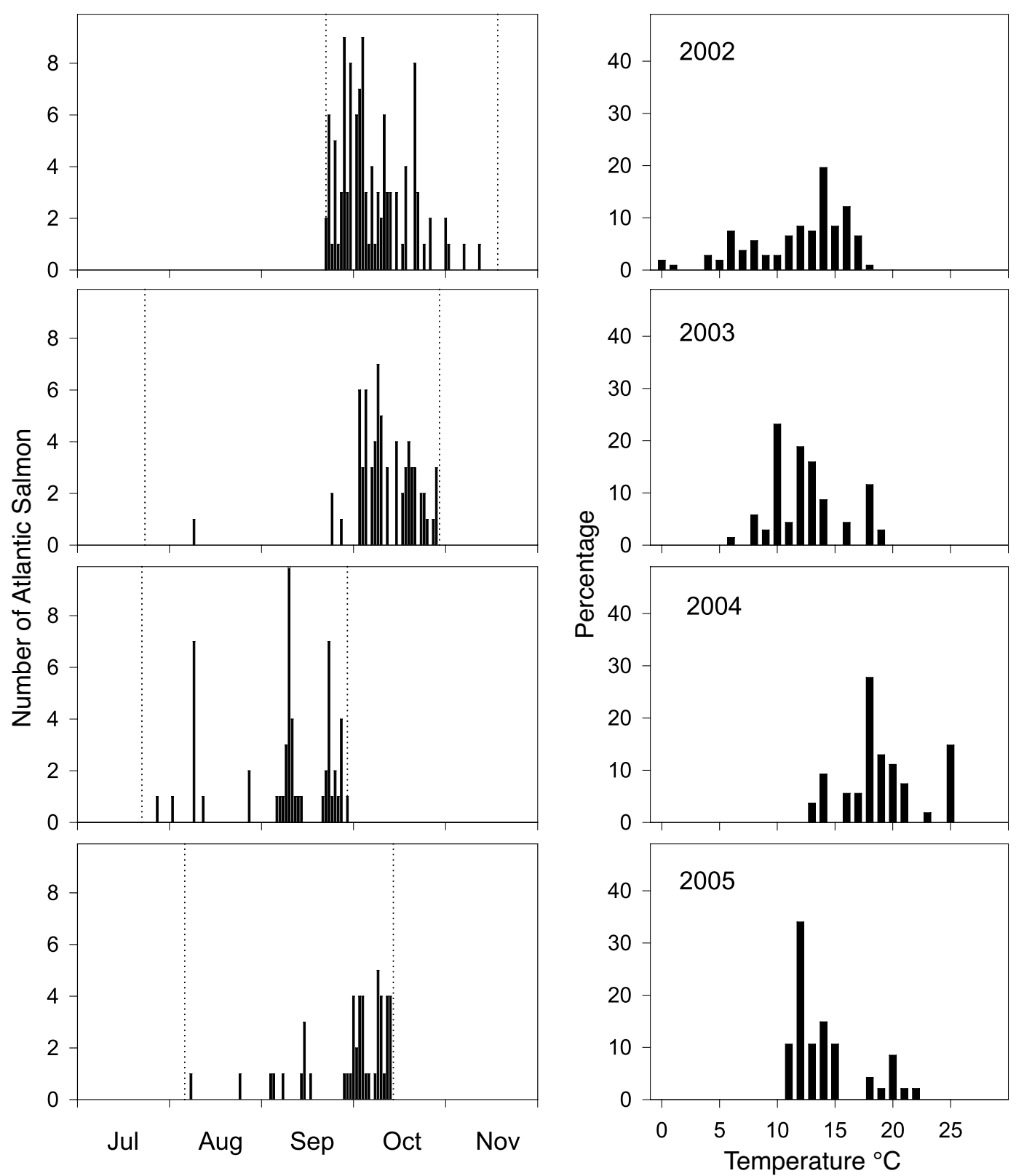

FIGURE 9. Daily catches of Atlantic Salmon (Salmo salar) from the combined catches of both traps (MT + RT) in the Tabusintac River 2002-2005. Dotted vertical lines represent the beginning and end of sampling. Right side panels show catches (as percent) in relation to temperature.

acteristic of temperate and boreal estuaries were taken at our two sampling sites. These include Anguillidae (freshwater eels), Clupeidae (herrings), Gadidae (cods), Gasterosteidae (sticklebacks), Moronidae (temperate basses), Pleuronectidae (right eyed flounders), Salmonidae (trout, salmon) and Osmeridae (smelt, capelin). With the exceptions of the Gadidae and Pleuronectidae, all of these families have strong affinities to north temperate estuaries with a high proportion of species feeding, spawning or using the estuary as a migration corridor to fresh water spawning sites. Gadidae and Pleuronectidae differ from the other families 

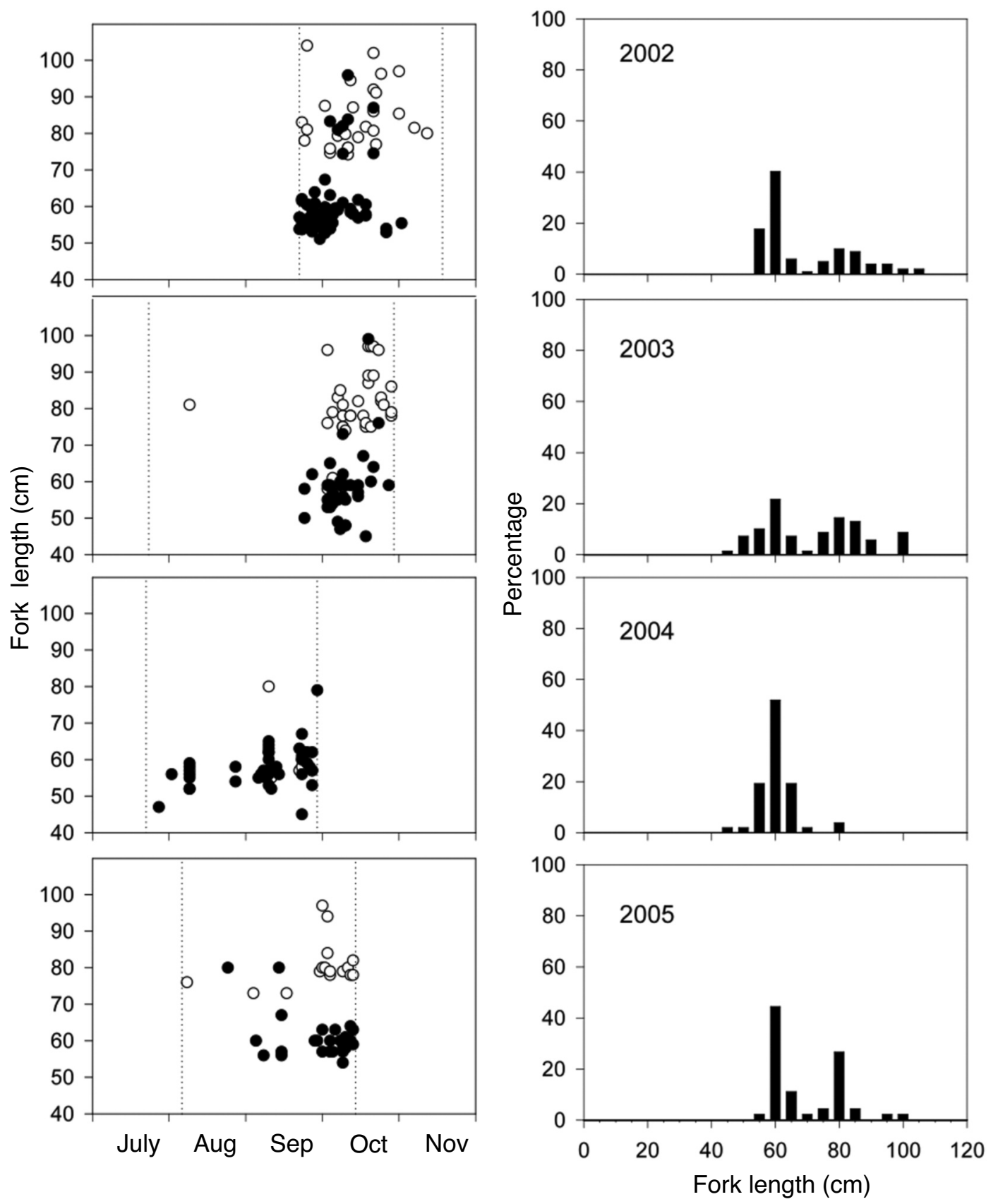

FIGURE 10. Daily lengths of individual male $(\bullet)$ and female (o) Salmon (Salmo salar) and length frequencies (as percent) calculated from both traps combined (MT + RT) in the Tabusintac River 2002-2005. Dotted vertical lines represent the beginning and end of sampling.

in that most species in these families spawn and complete their life cycle in marine waters (Scott and Scott 1988; Collette and Klein-MacPhee 2002). Exceptions include Microgadus tomcod (Gadidae) and Pseu- dopleuronectes americanus and Pleuronectes putna$m i$ (Pleuronectidae) all of which were taken in low salinity water in our study. Catches of both flatfish species were generally low $(<5)$ in our study with the 

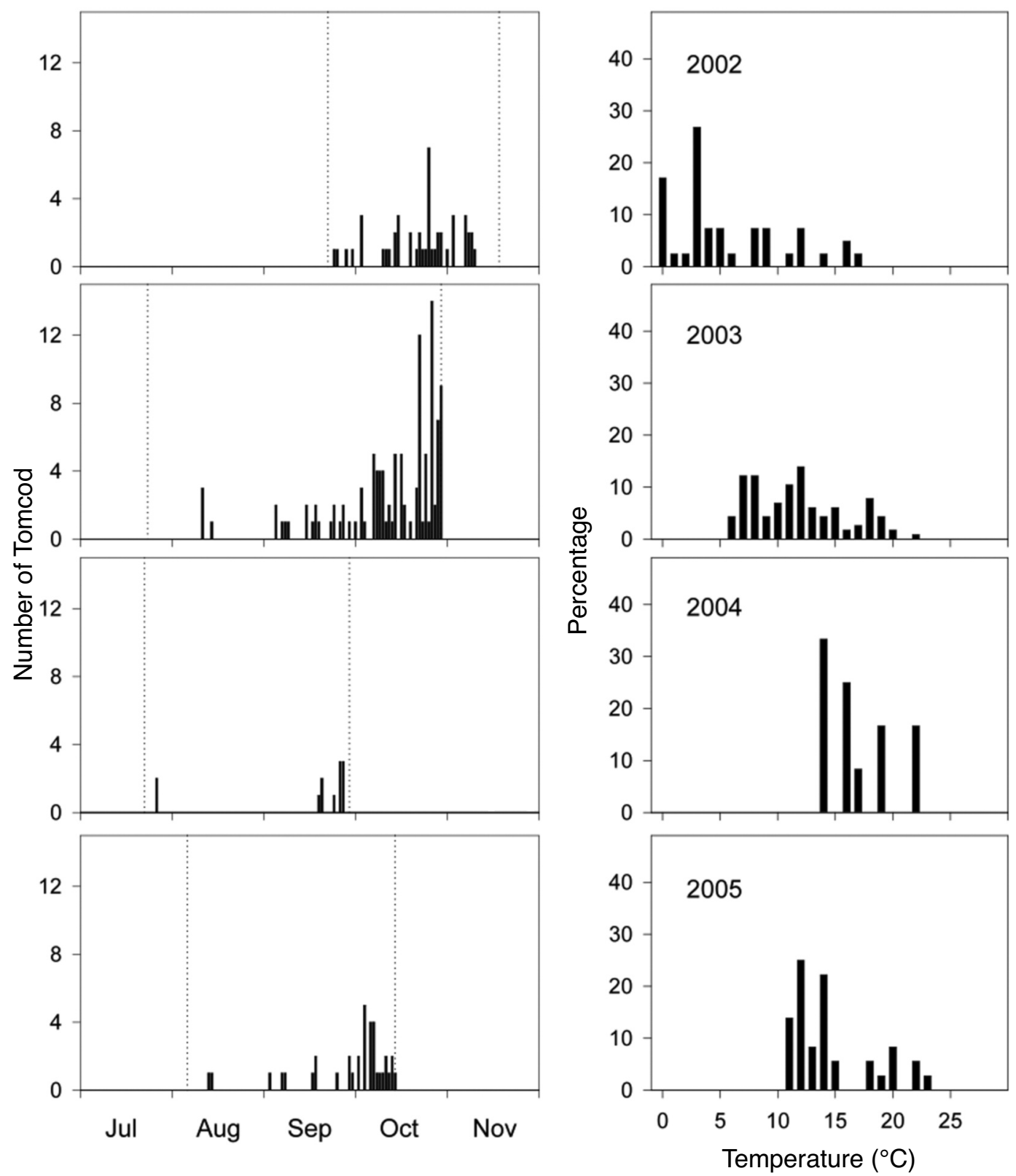

FIGURE 11. Daily catches of Tomcod (Microgadus tomcod) from the combined catches of both traps (MT + RT) in the Tabusintac River 2002-2005. Dotted vertical lines represent the beginning and end of sampling. Right side panels show catches (as percent) in relation to temperature.

exception of five days when catches exceeded 15 fish per day. Both species have been collected in the nearby Miramichi River and Estuary (Hanson and Courtenay 1996; 1997) and we observed approximately equal proportions of both species in the Tabusintac River in 2007 . We conclude that both species very likely occurred at our sites in 2002-2005.
Families that were not caught (Gasterosteidae), or that were poorly represented (Osmeridae) were likely present in greater numbers in the Tabusintac River Estuary but were not retained in our traps due to the relatively large mesh size $(50 \mathrm{~mm})$. Acipenseridae (sturgeons) is another important estuarine family off eastern Canada (Scott and Scott 1988). Neither of the 
two local sturgeon species (Acipenser oxyrinchus and A. brevirostrum; Atlantic and Shortnose sturgeons respectively) were taken in the Tabusintac River Estuary during our study, nor are they reported by Hanson and Courtenay (1995). McKenzie (1959), however, notes that up to half a dozen were taken each year in the main stem of Miramichi Bay from May to December. Chaput (1995) also notes that A. oxyrinchus is occasionally taken in the Miramichi River.

The overall composition of the Tabusintac River fish assemblage is influenced by pre- and post-spawning movements of several dominant anadromous species. April to June is the most intense period in terms of diversity and abundance of fishes migrating upstream and downstream in the nearby Miramichi River with summer having a less diverse fish fauna (Chaput 1995). Diversity and abundance increase again in fall (Chaput 1995). Given the close proximity of the two river systems, Chaput's observations appear to apply to the Tabusintac River. Early seasonal catches in our study were dominated by two post spawning Alosa species that had highest catches from mid July to early August. This is approximately two months after A. pseudoharengus is reported to spawn (May to June) in the Miramichi River (McKenzie 1959). High catches of these two species in the Tabusintac River decline shortly after mid August ( $<10$ fish per day). Hence, the large catches we report (sometimes $>200$ fish per day) from mid July to early August likely consist of post spawning fish moving downstream. Spawning times for the Blueback Herring (A. aestivalis) are poorly known (Scott and Scott 1988) due to difficulties distinguishing these two species, but are reported to be 10-14 days after $A$. pseudoharengus spawns (Chaput and Atkinson 2001). Consequently “... Bluebacks spawn later than Alewifes, the beginning of their spawning run commencing when the Alewife run is declining. Thus the spawning runs of the two species are reported to overlap when both species use the same spawning stream" (Scott and Scott 1988:103).

The Alosa upstream spawning migration is related to water temperature and occurs earlier in the southern part of the range (Scott and Crossman 1998). The minimum spawning temperature for these two species is $10-14^{\circ} \mathrm{C}$ with spawning ceasing at approximately $27^{\circ} \mathrm{C}$ (Jones et al. 1978). Water temperature in the Tabusintac River peaked in late July $\left(20-25^{\circ} \mathrm{C}\right)$ at about the time when catches of these two species were highest in our study. This supports the observation that most of the Alosa caught in the Tabusintac River during our study were post spawned fish on their way downstream. Further support for the Alosa caught in this study being post spawned fish comes from observations during the last half of June when the two box traps were being built at the MT and RT sites. During this time (about 2 weeks) high densities of Alosa were occasionally observed in very shallow water $(<60 \mathrm{~cm})$ along the rocky shore. Fish were observed to be cir- cling close together, sometimes with half of their body visible above the water. It was not uncommon to hear fish splashing in shallow water at this time. The water became very murky due to milt being released during spawning and due to the loss of scales and mucus from fish in close contact. The mud substratum was also disturbed and suspended in the shallow water. This observation, made several times by AMH is very similar to observations of McKenzie (1959: 813) for Alosa spawning in the Miramichi River: "As they [Alosa] move upstream, many of them close to shore, groups of fish are often seen swimming rapidly anti-clockwise in a circle 1-2 $\mathrm{m}$ wide. In a matter of seconds the socalled nuptial dance or swim ends in a big splash".

Catostomus commersoni is next in the phenological succession of dominant species taken in the Tabusintac River after Alosa spp. Catostomus commersoni is a member of the sucker family Catostomidae, a family of freshwater fishes found only in the North Hemisphere. It occurs throughout much of New Brunswick (McKenzie 1959; Scott 1967; Scott and Crossman 1998). The biology of White Sucker in Canada is well known as a result of its abundance and widespread distribution and is summarized by Scott and Crossman (1998). Catches of C. commersoni, with the exception of 2003 were generally punctuated and usually of short duration. Catostomus commersoni was most abundant from late August to early October $\left(20-10^{\circ} \mathrm{C}\right)$ and was the only dominant freshwater species taken. Spawning occurs from early May to early June, sometimes in lakes, but usually in gravel substrate of streams, when adults migrate from lakes at temperatures of approximately $10^{\circ} \mathrm{C}$ (Scott and Crossman 1998). We conclude that White Sucker taken in our traps were post spawned fish, given that adults begin moving off the spawning grounds to lakes 10-14 days after spawning begins (Scott and Crossman 1998), and that we did not observe eggs or milt being released when the many fish collected were handled and removed from the traps each day. Consequently, it is possible that White Sucker were moving both upstream and downstream when caught, given that tributaries to lakes and ponds occur in both directions from our trap sites. Scott and Crossman (1998) concluded that movements (other than spawning migrations and the general tendency to move offshore with increasing age) are random, probably in response to temperature.

The poorly defined catches of $C$. commersoni from late August to early October were followed by low catches of Microgadus tomcod, Anguilla rostrata and Salmo salar in September, October and November. Most of the catch data for these species also appears to be related to spawning migrations. Catches of Microgadus tomcod were highest when water temperature was declining in September and October $\left(17-3^{\circ} \mathrm{C}\right)$, a time of year when feeding is reported to be high (Collette and Klein-MacPhee 2002). Mean catches prior to September were very low ( $<3-4$ fish per trap day). 
During autumn, large numbers of adults return to the Miramichi Estuary (just south of the Tabusintac River) and are caught downstream of Newcastle by bottom trawls and smelt traps (McKenzie 1959; Hanson and Courtenay 1995). Our small catches of Tomcod in autumn just precede the main upstream migration that takes place in November and early December in the Tabusintac and Miramichi Rivers (McKenzie 1959). Spawning occurs in December and January near the upper limit of saltwater intrusion (McKenzie 1959; Pearcy and Richards 1962; Booth 1967; Fahay 2007) usually in association with ice cover (Vladykov 1955; Booth 1967; Collette and Klein-MacPhee 2002). After spawning, adult Tomcod migrate downstream from February to May (Vladykov 1955; McKenzie 1959). Spawning occurs when Tomcod are 17-18 cm (Vladykov 1955; Collette and Klein-MacPhee 2002). Length of M. tomcod in our study was not measured, but most were $14-22 \mathrm{~cm}$. Weakly adhesive demersal eggs (Fahay 2007) stick together in masses or adhere to algae or stones on sand or gravel bottoms (Booth 1967; Collette and Klein-MacPhee 2002). Eggs can accumulate in the interstitial spaces of ice and are transported downriver during ice breakup in spring and hatch (R. Cunjak personal communication). Incubation time at $0^{\circ} \mathrm{C}$ is $44-70$ days (Leim and Scott 1966) and larvae were taken in May and June in low salinity waters of the Miramichi Estuary (Locke and Courtenay 1995).

Anguilla rostrata is another species with high catches in October when water temperature was declining $\left(17\right.$ to $\left.<10^{\circ} \mathrm{C}\right)$. Once abundant in streams and rivers of eastern Canada (McKenzie 1959; Scott and Crossman 1998), this species now shows substantial declines in commercial landings (Cairns 2005). Commercial fyke net catches in Atlantic Canada are highest in autumn (Cairns 2005) when mature American Eels migrate downstream to marine spawning sites (Collette and Klein-MacPhee 2002).

Eels were not sexed in our study but most (83\%) were greater than $60 \mathrm{~cm} \mathrm{TL}$ and appear to be predominantly female. Sex determination in Anguilla rostrata appears to be strongly influenced by density, with high densities promoting the production of males (COSEWIC 2006a). Eels in the upper St. Lawrence River and Lake Ontario are virtually all females and females dominate in many other locations in Canada (COSEWIC 2006a). Females mature at and attain larger sizes than males (Scott and Scott 1988; Collette and KleinMacPhee 2002). The smallest mature males measure $28 \mathrm{~cm}$. Females mature at approximately $45 \mathrm{~cm}$ (Collette and Klein-MacPhee 2002). Eels found in rivers flowing into the Gulf of Maine that are greater than $60 \mathrm{~cm}$ are almost certain to be female (Collette and Klein-MacPhee 2002). In Canadian waters, females can exceed $100 \mathrm{~cm}$ whereas males seldom exceed $61 \mathrm{~cm}$ (Scott and Scott 1988). Bouillon and Haedrich (1985) did not report any males over $40 \mathrm{~cm}$ from Newfound- land rivers. If these observations are applicable to the Tabusintac River then the majority of Eels caught in our study, most of which were greater than $60 \mathrm{~cm}$, were predominantly female. Hence, the high proportion of large Eels taken in the Tabusintac River in autumn (the time reported for downstream spawning migrations; Collette and Klein-MacPhee 2002) suggests that these were maturing Eels migrating downstream on their way to marine spawning sites.

Eels were common from spring to autumn as evidenced by catches in the commercial fishery in the Miramichi River and estuary (Hanson and Courtenay 1995). This estuarine occurrence is also noted by McKenzie (1959) who reported up to $6818 \mathrm{~kg}$ taken in Miramichi Bay and adjacent rivers by commercial fishers in some years and that historically, great quantities were taken in holes through the ice with spears, a fishery that continues in parts of Atlantic Canada (Cairns 1997). Recent work based on otolith strontiumto-calcium ratios from two estuaries in Prince Edward Island indicates $A$. rostrata can complete its entire life cycle in the sea by making extensive use of estuaries (Lamson et al. 2006). Hence, the catadromy paradigm for the American Eel from Atlantic Canada is overturned (Lamson et al. 2006). The high representation of exclusive salt-water residency in Eels $(84.6 \%)$ suggests that non-catadromy may be an important and common pattern for the American Eel (Lamson et al. 2006) although some undoubtly show both patterns.

Highest catches of $S$. salar occurred in September and October at approximately $15^{\circ} \mathrm{C}$ when temperatures were decreasing. All Atlantic Salmon taken in our traps were adults $($ most $>60 \mathrm{~cm}$ ) that were migrating upstream in October and November (Scott and Scott 1988). Atlantic Salmon were also caught in July $(2004, n=1)$ and August (2003, $n=1 ; 2004, n=11$; $2005, n=2)$. This is weeks before the run starts in September. Atlantic Salmon returning to the Tabusintac River are a mixture of fish that have spent one or two winters at sea, with most small Atlantic Salmon being males and most large Salmon being females, a pattern that is consistent for salmon returning to natal rivers in the Gulf of St. Lawrence and Québec (O'Connell et al. 2006). The largest Atlantic Salmon, those few fish that were greater than $95 \mathrm{~cm}$, appear to be three-sea-winter fish (O'Connell et al. 2006) that are predominantly female.

Over the four-year duration of our study, numbers of Salmon decreased from $2002(n=113)$ to 2005 $(n=38)$ however sampling effort was not standardized due to the different start and finish dates of sampling each year. Future sampling at these sites must standardize the size and type of traps used as well as the start and finish dates of sampling to make among year comparisons meaningful. For example, sampling ceased in late September 2004. This is before most Salmon arrive in the fall migration (usually early October, as observed in 2002, 2003, 2005) and this result- 
ed in only 46 common days of sampling from 2003 to 2005 (12 August to 26 September). Consequently it is difficult to draw conclusions regarding increasing or decreasing abundance of this much prized and once heavily exploited species. The ideal window of sampling to appropriately monitor the fall migration of Salmon returning to the Tabusintac River Estuary would appear to be 1 August to 31 October (possibly later). Future monitoring of the Tabusintac River population in August, September and October would provide data to assess the conservation status of this species, an important objective given that the inner Bay of Fundy population as has been listed by the Committee on the Status of Endangered Wildlife in Canada (COSEWIC) as Endangered and that many other wild populations of $S$. salar are now extinct on a global scale (COSEWIC 2006b). Data that are available for catches of $S$. salar on the Tabusintac River for traps at the two sampling sites during the common days of sampling over the last decade are quite variable, but do show a decreasing trend when combined with data in Table 2 due to the high catches in 1999 (1998: 43; 1999: 176; 2002: 30+; 2003: 4; 2004: 51; 2005: 12; 2006: 9; 2007: 10; 2008: 16). No sampling was done in 2000 and 2001 and there were only eight days of sampling within the 12 August to 26 September window of common days in 2002 when 30 Atlantic Salmon were caught (Figure 9).

Striped Bass were collected each month but catches tended to be highest from September to early November when water temperature was decreasing from approximately 17 to $3^{\circ} \mathrm{C}$. Striped Bass apparently spawn only in two locations in Atlantic Canada, the Stewiacke River, a tributary of the Shubenacadie River in the lower Bay of Fundy and in the Miramichi River, just south of the Tabusintac River (COSEWIC 2004). Spawning occurs in May or June in fresh or slightly brackish water at temperatures greater than $10^{\circ} \mathrm{C}$ (Raney et al. 1952; Scott and Scott 1988). After spawning, adults (i.e., males $>30 \mathrm{~cm}$ [age 3]; females $>40 \mathrm{~cm}$ [ages 4-5]; COSEWIC 2004) move down river and enter coastal estuaries where they may remain, or migrate further along the coast to feed (Douglas et al. 2003). When water temperature decreases in autumn, Striped Bass gradually migrate upriver where they overwinter (Magnin and Beaulieu 1967; Jessop 1991). A particularly unique feature of Canadian Striped Bass populations is that they overwinter in rivers or lakes under ice in order to escape cold ocean temperatures (COSEWIC 2004). These repeated upriver migrations in autumn, make deciphering the life history and movements of Striped Bass challenging. This is due, in part to Striped Bass being an amphidromous species (Chaput 1995), a diadromous species that migrates between marine and freshwater but not for the sole purpose of spawning.

Striped Bass were caught throughout summer in the Tabusintac River. Three size modes (approximately
$10-15,25-35,45-65 \mathrm{~cm}$ ) were observed in some years. Some modes show evidence of growth as indicated by very slight positive slopes of increasing length (Figure 4) which we speculate is suggestive of Striped Bass remaining in the Tabusintac River and growing during that time. Other size modes show no evidence of growth, suggesting a more rapid turnover in the vicinity of our traps. Catches of Striped Bass in our traps on the Tabusintac River were very pulsed, especially in 2003 (Figure 3). Three peaks in catches of Striped Bass were reported by Chaput and Randall (1990) on the Miramichi River, the second (summer) and third (fall) of which were believed to correspond to movements for feeding. We see no evidence of a pulse of big fish returning in autumn to migrate upstream with the possible exception of some very large fish $(>70 \mathrm{~cm})$ in 2002 , the year that sampling extended latest in the autumn (8 November; Table 1 ).

Of particular interest is the capture of Striped Bass in $2003(n=53)$ and $2005(n=6)$ that were less than $10 \mathrm{~cm}$. These are young-of-the-year fish, just three to four months old (Douglas et al. 2003) that have apparently migrated from the closest known spawning grounds in the Miramichi River. If these YOY originate from an early June spawning in the Miramichi River (COSEWIC 2004) then this is a conservatively estimated minimum distance of $60 \mathrm{~km}$ travelled from early June to being collected in our traps $14 \mathrm{~km}$ up the Tabusintac River in early August and September. Some of these YOY are less than $6 \mathrm{~cm}$ and much of this distance is against prevailing currents indicating that these fish are capable of moving considerable distances at small sizes.

\section{Acknowledgments}

This research was supported by the Burnt Church First Nation - Salmon Assessment Program coordinated by Clark Dedam and supervised by Donnie Swasson. Research was funded by the Department of Fisheries and Oceans in Moncton, New Brunswick. We are very grateful to the fishing crews which included: Noel Augustine, Harry Barnaby, Andy Dedam, Peter Dedam, Gregory Denny, Raymond Mitchell, Clayton Paul, Emerson Paul Sr., Herbie Somerville and Wesley Somerville. We also thank Kelly Munkittrick and Scott Douglas (DFO Moncton) and two anonymous reviewers for commenting on the manuscript.

\section{Literature Cited}

Booth, R. A. 1967. A description of the larval stages of the tomcod, Microgadus tomcod, with comments on its spawning ecology. PhD. thesis. University of Connecticut. 53 pages.

Bouillon, D. R., and R. L. Haedrich. 1985. Growth of silver eels (Anguilla rostrata) in two areas of Newfoundland. Journal of the Northwest Atlantic Fishery Science 6: 95100.

Cairns, D. K. 1997. Prince Edward Island eels, gaspereau, silversides and smelts. Stock status report D3-18. 5 pages. 
Cairns, D. K. 2005. An eel manager's toolbox for the southern Gulf of St. Lawrence. Canadian Science Advisory Secretariat, Research Document 2005/046. 19 pages.

Chaput, G. J. 1995. Temporal distribution, spatial distribution, and abundance of diadromous fish in the Miramichi River Watershead. Pages 121-139 in Water, Science and the Public: The Miramichi Ecosystem. Edited by E.M.P. Chadwick. Canadian Special Publication of Fisheries and Aquatic Science 123.

Chaput, G. J., and G. Atkinson. 2001. The gaspereau fisheries (Alosa pseudoharengus and A. aestivalis) of the Miramichi River with updates on the fishery of the Richibucto River of Gulf New Brunswick, 1997 to 2000. Canadian Science Advisory Secretariat Research Document 2001/047. 39 pages.

Chaput, G. J., and R. G. Randall. 1990. Striped bass (Morone saxatilis) from the Gulf of St. Lawrence. DFO Canadian Atlantic Fisheries Scientific Advisory Committee Research Document 90/71: 29 pages.

Collette, B. B., and G. Klein-MacPhee. 2002. Bigelow and Schroeder's Fishes of the Gulf of Maine, $3^{\text {rd }}$ Edition. Smithsonian Institution Press, Washington. 629 pages.

Comeau, N. 2001a. Provincial Water Classification of the Tabusintac River Watershed. Tabusintac Watershed Association. 68 pages.

Comeau, N. 2001b. Resource Mapping: Traditional Ecological Knowledge for the Tabusintac Watershed, Provincial Atlas. Tabusintac Watershed Association. 62 pages.

COSEWIC. 2004. COSEWIC assessment and status report on the striped bass Morone saxatilis in Canada. Committee on the Status of Endangered Wildlife in Canada, Ottawa. 43 pages.

COSEWIC. 2006a. COSEWIC assessment and update status report on the American Eel Anguilla rostrata in Canada. Committee on the Status of Endangered Wildlife in Canada, Ottawa. 71 pages.

COSEWIC. 2006b. COSEWIC assessment and update status report on the Atlantic salmon Salmo salar (Inner Bay of Fundy populations) in Canada. Committee on the Status of Endangered Wildlife in Canada, Ottawa. 45 pages.

Curry, R. A. 2007. Late glacial impacts on dispersal and colonization of Atlantic Canada and Maine by freshwater fishes. Quaternary Research 67: 225-233.

Dahlberg, M. D., and E. P. Odum. 1970. Annual cycles of species occurrence, abundance, and diversity in Georgia estuarine fish populations. The American Midland Naturalist 83: 382-392.

deBruyn, A. M. H., and J. J. Meeuwig. 2001. Detecting lunar cycles in marine ecology: periodic regression versus categorical ANOVA. Marine Ecology Progress Series 214: 307-310.

Douglas, S. G., R. G. Bradford, and G. Chaput. 2003. Assessment of striped bass (Morone saxatilis) in the Maritime Provinces in the context of species at risk. Department of Fisheries and Oceans Canadian Science Advisory Secretariat Research Document 2003/008. 55 pages.

Dunfield, R. W. 1974. Types of commercial salmon fishing gear in the maritime provinces 1971. Pages 22-23 in Resource Development Branch, Fisheries and Marine Service Department of the Environment. Publication Number MAR/N-74-1. Halifax, Nova Scotia.

Fahay, M. 2007. Early stages of fishes in the western north Atlantic Ocean (Davis Strait, southern Greenland and Flemish Cap to Cape Hatteras). Volume 1: Acipenseriformes through Syngnathiformes. 931 pages.
Gibson, R. N., L. Robb, M. T. Burrows, and A. D. Ansell. 1996. Tidal, diel and longer term changes in the distribution of fishes on a Scottish sandy beach. Marine Ecology Progress Series 130: 1-17.

Haedrich, R. L. 1983. Estuarine fishes. Pages 183-207 in Estuaries and enclosed seas. Edited by B. H. Ketchum. Ecosystems of the World 26. Elsevier Scientific. New York.

Hanson, J. M., and S. C. Courtenay. 1995. Seasonal abundance and distribution of fishes in the Miramichi Estuary. Pages 141-160 in Water, Science and the Public: The Miramichi Ecosystem. Edited by E. M. P. Chadwick. Canadian Special Publication of Fisheries and Aquatic Science 123.

Hanson, J. M., and S. C. Courtenay. 1996. Seasonal use of estuaries by winter flounder in the southern Gulf of St. Lawrence. Transactions of the American Fisheries Society 125: 705-718.

Hanson, J. M., and S. C. Courtenay. 1997. Seasonal distribution, maturity, condition, and feeding of smooth flounder (Pleuronectes putnami) in the Miramichi Estuary, southern Gulf of St. Lawrence. Canadian Journal of Zoology 75: 1226-1240.

Jessop, B. M. 1991. The history of striped bass fishery in the Bay of Fundy. Canadian Technical Report of Fisheries and Aquatic Sciences 1832.

Jones, P. W., F. D. Martin, and J. D. Hardy, Jr. 1978. Development of Fishes of the Mid-Atlantic Bight: An Atlas of Egg, Larval and Juvenile Stages, Volume 1. Acipenseridae through Ictaluridae. United States Fish and Wildlife Service, Biological Service Program. FWS/OBS78/12, 366 pages.

Laevastu, T., and M. L. Hayes. 1981. Fisheries oceanography. Fishing News Books Ltd., Farnham, England. 199 pages.

Lamson, H. M., Jen-Chieh Shiao, Yoshiyuki Iizuka, WannNian Tzeng, and D. K. Cairns. 2006. Movement patterns of American eels (Anguilla rostrata) between saltand freshwater in a coastal watershed, based on otolith microchemistry. Marine Biology 149: 1567-1576.

Lazzari, M. A., S. Sherman, C. S. Brown, J. King, B. J. Joule, S. B. Chenoweth, and R. W. Langton. 1999. Seasonal and annual variations in abundance and species composition of two nearshore fish communities in Maine. Estuaries 22: 636-647.

Leim, A. H., and W. B. Scott. 1966. Fishes of the Atlantic Coast of Canada. Fisheries Research Board of Canada, Bulletin Number.155. 485 pages.

Locke, A., and S. C. Courtenay. 1995. Ichthyoplankton and invertebrate zooplankton of the Miramichi Estuary: 1918-1993. Pages 97-120 in Water, Science and the Public: The Miramichi Ecosystem. Edited by E. M. P. Chadwick. Canadian Special Publication of Fisheries and Aquatic Science 123.

Magnin, E., and G. Beaulieu. 1967. Le bar, Roccus saxatilis (Walbaum), du fleuve Saint-Laurent. Le Naturaliste canadien 94: 539-555.

McDowall, R. M. 1987. The occurrence and distribution of diadromy among fishes. American Fisheries Society Symposium 1: 1-13.

McHugh, J. L. 1967. Estuarine nekton. Pages 581-620. Estuaries. Edited by G. H. Lauff. American Association for the Advancement of Science. Special Publication 83.

McHugh, J. L. 1976. Estuarine fisheries: are they doomed? Pages 15-27 in Estuarine Processes, 1. Uses, Stresses, and 
Adaptation to the Estuary. Edited by M. Wiley. Academic Press, New York.

McKenzie, R. A. 1959. Marine and freshwater fishes of the Miramichi River and estuary, New Brunswick. Journal of the Fisheries Research Board of Canada 16: 807-833

Methven, D. A., R. L. Haedrich, and G. A. Rose. 2001. The fish assemblage of a Newfoundland estuary: daily, monthly, and annual variation. Estuarine Coastal and Shelf Science 52: 669-687.

O'Connell, M. F., J. B. Dempson, and G. Chaput. 2006. Aspects of the life history, biology, and population dynamics of Atlantic Salmon (Salmo salar L.) in Eastern Canada. Canadian Science Advisory Secretariat Research Document 2006/014.

Pearcy, W. G., and S. W. Richards. 1962. Distribution and ecology of fishes of the Mystic River estuary. Connecticut. Ecology 43: 129-214.

Pollard, D. A. 1981. Estuaries are valuable contributors to fisheries production. Australian Fisheries 40: 7-9.

Potter, I. C., L. E. Beckley, A. K. Whitfield, and R. C. J. Lenanton. 1990. Comparisons between the roles played by estuaries in the life cycles of fishes in temperate Western Australia and Southern Africa. Environmental Biology of Fishes 28: 143-178.
Raney, E. C., E. F. Tresselt, E. H. Hollis, V. D. Vladykov, and D. H. Wallace. 1952. The striped bass Roccus saxatilis. Bulletin Bingham Oceanographic Collection Peabody Museum of Natural History, Yale University 14, 177 pages.

Scott, W. B. 1967. Freshwater Fishes of Eastern Canada. $2^{\text {nd }}$ Edition. University of Toronto Press. 137 pages.

Scott, W. B., and E. J. Crossman. 1998. The Freshwater Fishes of Canada. Galt House Publications Ltd., Oakville, Ontario, Canada. 966 pages.

Scott, W. B., and M. G. Scott. 1988. Atlantic Fishes of Canada. University of Toronto Press. Canadian Bulletin Fisheries Aquatic Sciences 219, 625 pages.

Sosa-Lopez, A., and D. Mouillot. 2007. Spatiotemporal segregation regulates species richness along biomass gradients in estuarine fish assemblages. Marine Ecology Progress Series 342: 217-226.

Taylor, E. B. 2004. An analysis of homogenization and differentiation of Canadian freshwater fish faunas with an emphasis on British Columbia. Canadian Journal of Fisheries and Aquatic Science 61: 68-79.

Vladykov, V. D. 1955. Fishes of Quebec. Cods. Department of Fisheries Quebec. Album 4. 12 pages.

Received 9 January 2009

Accepted 9 July 2009 